\title{
PENGARUH METODE CERAMAH DAN DISKUSI DALAM PENINGKATAN PENGETAHUAN HIV/AIDS PADA SISWA SMP ARRAHMAN KOTA TANGERANG 2014
}

\begin{abstract}
Wasludin *
Abstrak

Sasaran strategis Kemenkes tahun 2010 - 2014 yaitu menurunnya prevalensi HIV pada penduduk usia 15-49 tahun menjadi $<0,5 \%$, meningkatnya persentase penduduk usia 15-24 tahun yang memiliki pengetahuan komprehensif tentang HIV-AIDS dari 65\% menjadi 95\%, dan meningkatnya jumlah penduduk usia 15 tahun atau lebih yang menerima konseling dan tes HIV dari 300.000 menjadi 700.000. Kondisi tahun 2011, data-data menunjukan epidemi jalan terus dengan sangat cepat, pengetahuan masyarakat masih rendah, layanan kurang optimal, cakupan masih rendah, dan akses masyarakat terbatas. Tujuan Penelitian adalah Ingin mengetahui metode yang lebih baik dan cocok untuk menyampaikan edukasi tentang HIV/AIDS kepada siswa sehingga dapat meningkatkan pengetahuan siswa tentang HIV/AIDS. Desain penelitian yang digunakan adalah eksperimental dengan pendekatan rancangan eksperimental ulang (pre test-post test controle group design), yaitu subjek dibagi 2 kelompok, pada masing-masing kelompok dilakukan pengukuran sebelum dan sesudah perlakuan yang berbeda.
\end{abstract}

Hasil penelitian menunjukkan Pengetahuan responden tentang HIV/AIDS meningkat antara sebelum dan sesudah penyuluhan kesehatan baik dengan metode ceramah maupun dengan metode diskusi. Nilai rata-rata pengetahuan dengan metode ceramah lebih tinggi dibadingkan dengan nilai rata-rata pengetahuan dengan metode diskusi. Hasil uji statistik diperoleh ada perbedaan yang signifikan antara nilai pengetahuan sebelum dan sesudah dilakukan penyuluhan kesehatan dengan menggunakan metode ceramah $(\mathrm{p}=0,000)$, ada perbedaan yang signifikan antara nilai pengetahuan sebelum dan sesudah dilakukan penyuluhan kesehatan dengan menggunakan metode diskusi $(\mathrm{p}=0,003)$, dan ada perbedaan yang signifikan nilai ratarata pengetahuan responden antara metode ceramah dan metode diskusi $(\mathrm{p}=0,000)$.

Kesimpulan : Ada perbedaan yang signifikan nilai rata-rata pengetahuan responden antara metode ceramah dan metode diskusi $(\mathrm{p}=0,000)$.

Kata Kunci : HIV/AIDS, pengetahuan, ceramah, diskusi

Daftar Pustaka : 7 buku, 4 Web

* Dosen Jurusan Keperawatan Poltekkes Kemenkes Banten 


\title{
The INFLUENCE of METHODS LECTURES and DISCUSSIONS in INCREASED KNOWLEDGE of HIV/AIDS in STUDENTS of JUNIOR ARRAHMAN TANGERANG 2014
}

\author{
Wasludin *
}

\begin{abstract}
Research objectives: want to know a better method and is suitable for delivering education about HIV/AIDS to the students so as to enhance the knowledge of students about HIV/AIDS

Research methods: based on the above research objectives, research design used was experimental design experimental approach (pre test - post test controle group design), i.e. the subject divided two groups, on each the group performed the measurements before and after different treatment.
\end{abstract}

Results of research: knowledge of respondents about HIV/AIDS is increasing among before and after health education either by lecture method or by a method of discussion. The average value of knowledge by lecturing method dibadingkan with higher average value of knowledge with the method of discussion.

The results of statistical tests are obtained there is a significant difference between the value of knowledge before and after health education carried out by using the method of lecture ( $\mathrm{p}=$ 0.000), there is a significant difference between the value of knowledge before and after health counseling is done by using the method of discussion $(\mathrm{p}=0.003)$, and there is a significant difference in the average value of the knowledge of the respondents between methods of lecture and discussion methods $(\mathrm{p}=0.000)$.

Conclusion: there is a significant difference in the average value of the knowledge of the respondents between methods of lecture and discussion methods $(\mathrm{p}=0.000)$.

Keywords: HIV/AIDS, knowledge, lectures, discussion

* Associate Professor at the Department of nursing of Tangerang, JL. Dr. Sitanala Tangerang 


\section{Pendahuluan}

Berdasarkan data dari Ditjen PP \& PL Kemenkes (2013), angka kejadian HIV/AIDS di Indonesia tahun ke tahun meningkat. Jumlah kasus baru tahun 2011 terdapat 21.031 penderita HIV dan 7.286 AIDS, tahun 2012 terdapat 21.511 penderita HIV dan 8.610 AIDS, dan tahun 2013 terdapat 29.037 penderita HIV dan 5.608 AIDS, sehingga total penderita akhir Desember 2013 sebanyak 179.764 orang yang teridiri dari 127.416 HIV dan 52.348 AIDS dengan jumlah kematian 9.585 orang. Sebagian dari penderita HIV/AIDS tersebut adalah anak remaja umur 15 - 19 tahun sebanyak 1.710 orang.

Sasaran strategis Kemenkes tahun 2010 - 2014 yaitu menurunnya prevalensi HIV pada penduduk usia 15-49 tahun menjadi $<0,5 \%$, meningkatnya persentase penduduk usia 15-24 tahun yang memiliki pengetahuan komprehensif tentang HIVAIDS dari $65 \%$ menjadi 95\%, dan meningkatnya jumlah penduduk usia 15 tahun atau lebih yang menerima konseling dan tes HIV dari 300.000 menjadi 700.000. Kondisi tahun 2011, data-data menunjukan epidemi jalan terus dengan sangat cepat, pengetahuan masyarakat masih rendah, layanan kurang optimal, cakupan masih rendah, dan akses masyarakat terbatas.

Selain memberikan pengetahuan melalui pendidikan, juga dapat dilakukan melalui memberikan informasi kesehatan. Dengan memberikan informasi tentang kebiasaan hidup sehat dan cara pencegahan penyakit diharapkan akan terjadi peningkatan pengetahuan sikap dan perilaku kesehatan dalam diri individu/kelompok sasaran yang berdasarkan kesadaran dan kemauan individu yang bersangkutan, (Notoatmodjo, 2007).

Dalam memberikan pendidikan kesehatan atau informasi kesehatan kepada para siswa atau sasaran dipergunakan berbagai metode dan media agar informasi yang disampaikan dapat diterima dan di pahami oleh sasaran sehingga dapat melakukan perilaku yang diharapkan. Dari berbagai metode dalam pendidikan kesehatan, metode ceramah dan tanya jawab merupakan metode yang sering digunakan oleh tenaga pendidik atau edukator kesehatan. Untuk mengetahui pengaruh penggunaan kedua metode tersebut dan metode mana yang cocok dan baik untuk meningkatkan pengetahuan siswa tentang kesehatan khususnya HIV/AIDS, peneliti melakukan percobaan manfaat penggunaan kedua metode tersebut pada siswa SMP Arrahman Kota Tangerang.

Secara umum tujuan penelitian ini ingin mengetahui metode yang lebih baik dan cocok untuk menyampaikan edukasi tentang HIV/AIDS kepada siswa sehingga 
dapat meningkatkan pengetahuan siswa tentang HIV/AIDS

\section{Metoda}

Berdasarkan tujuan penelitian di atas, desain penelitian yang digunakan adalah eksperimental dengan pendekatan rancangan eksperimental ulang (pre testpost test controle group design), yaitu subjek dibagi 2 kelompok, pada masingmasing kelompok dilakukan pengukuran sebelum dan sesudah perlakuan yang berbeda.

Karakteristik Sampel dalam penelitian ini adalah responden/siswa kelas VIII pada SMP Arrahman Kota Tangerang, baik laki-laki maupun perempuan yang bersedia menjadi responden penelitian. Sedangkan sampel pada penelitian ini diperlukan 42 orang responden yang dibagi menjadi 2 kelompok masing-masing 21 orang responden.

Analisa data yang digunakan dalam penelitian ini adalah analisa univariat yaitu untuk melihat distribusi frekuensi terhadap berbagai karakteristik pada variabel independent dan dependent dengan menggunakan distribusi frekuensi dan persentasi, kemudian dianalisis bivariat untuk melihat hubungan antara variabel independent dengan variavel dependent

\section{Hasil}

\section{Metode Ceramah}

Tabel 1

Distribusi frekuensi nilai pengetahuan responden tentang HIV/AIDS dengan metode Ceramah

\begin{tabular}{lcccc}
\hline Nilai & $\begin{array}{c}\text { Min } \\
\text { i }\end{array}$ & $\begin{array}{c}\text { Mak } \\
\text { s }\end{array}$ & $\begin{array}{c}\text { Mea } \\
\text { n }\end{array}$ & $\begin{array}{c}\text { Media } \\
\text { n }\end{array}$ \\
\hline $\begin{array}{l}\text { Sebelu } \\
\text { m }\end{array}$ & 48 & 88 & 62.29 & 60.00 \\
\hline Sesudah & 64 & 96 & 83.24 & 84.00 \\
\hline
\end{tabular}

\section{Tabel 2}

Distribusi rata-rata nilai pengetahuan sebelum dan sesudah penyuluhan dengan metode ceramah

\begin{tabular}{lcccc}
\hline Penilaian & Mean & SD & $\begin{array}{c}\text { P } \\
\text { value }\end{array}$ & $\mathrm{N}$ \\
\hline Sebelum & 62.29 & 10.551 & .000 & 21 \\
\cline { 1 - 3 } \cline { 1 - 2 } Setelah & 83.24 & 8.543 & & 21 \\
\hline
\end{tabular}

\section{Metode Diskusi}

Tabel 3

Distribusi frekuensi nilai pengetahuan responden tentang HIV/AIDS dengan metode diskusi

\begin{tabular}{ccccc}
\hline Nilai & Min & Maks & Mean & Median \\
\hline Sebelum & 44 & 76 & 56.57 & 56.00 \\
\hline Sesudah & 40 & 96 & 68.19 & 68.00 \\
\hline
\end{tabular}

Tabel 4

Distribusi rata-rata nilai pengetahuan sebelum dan sesudah penyuluhan dengan metode diskusi

\begin{tabular}{|c|c|c|c|c|}
\hline Penilaian & Mean & SD & $\begin{array}{c}\mathrm{P} \\
\text { value }\end{array}$ & $\mathrm{N}$ \\
\hline Sebelum & 56.57 & 8.225 & .003 & 21 \\
\hline Setelah & 68.19 & 15.309 & & 21 \\
\hline
\end{tabular}




\section{Metode Ceramah dan Diskusi}

Tabel 5

Distribusi frekuensi nilai pengetahuan responden tentang HIV/AIDS dengan metode ceramah dan diskusi

\begin{tabular}{ccccc}
\hline Nilai & Min & Maks & Mean & Median \\
\hline Sebelum & 44 & 88 & 59.43 & 60.00 \\
\hline Sesudah & 40 & 96 & 75.71 & 80.00 \\
\hline
\end{tabular}

Tabel 6

Distribusi nilai pengetahuan responden menurut metode penyuluhan

\begin{tabular}{ccccc}
\hline Metode & Mean & SD & P value & $\mathrm{N}$ \\
\hline Ceramah & 83,24 & 8,543 & .000 & 21 \\
& & & & \\
\cline { 1 - 3 } \cline { 5 - 6 } & & & & 21 \\
\hline
\end{tabular}

\section{Pembahasan}

Memperhatikan hasil di atas menunjukkan bahwa ada perbedaan meningkat antara nilai pengetahuan responden antara sebelum dan sesudah penyuluhan baik menggunakan metode ceramah maupun menggunakan metode diskusi. Hal ini sesuai dengan pendapat Bloom dalam Notoatmodjo (2010) bahwa tingkatan pengetahuan pertama yaitu tahu diartikan sebagai mengingat suatu materi yang telah dipelajari sebelumnya. Termasuk kedalam pengetahuan tingkat ini adalah mengingat kembali (recal) sesuatu yang spesifik dari seluruh bahan yang dipelajari atau rangsangan yang telah diterima.

Nilai rata-rata pengetahuan responden dengan mengunakan metode ceramah lebih tinggi (72.76) dibandingkan dengan nilai rata-rata pengetahuan responden dengan menggunakan metode diskusi (62.00). Pengetahuan responden tentang HIV/AIDS sudah termasuk kategori cukup baik karena nilai rata-rata mereka 56 - 75, ini sesuai dengan pendapat Arikunto (2006) dalam Wawan (2010), klasifikasi pengetahuan dalam sebuah penelitian dapat dikategorikan menjadi tiga kategori tingkat pengetahuan, yaitu :

a. Seseorang dikatakan baik jika mampu menjawab $76 \%$ - 100\% dari soal yang disajikan. Berarti orang tersebut mengetahui hal tersebut dengan baik (tahu).

b. Cukup baik jika mampu menjawab $56 \%$ - $75 \%$ dari soal yang disajikan. Berarti orang tersebut cukup mengetahui hal tersebut dengan baik (cukup tahu).

c. Kurang baik jika mampu menjawab < $56 \%$ dari soal yang disajikan. Berarti orang tersebut kurang mengetahui hal tersebut dengan baik (kurang tahu).

Responden dapat mengingat kembali pengetahuan yang diperoleh melalui metode ceramah dan diskusi yang dibuktikan dengan adanya peningkatan rata-rata nilai sebelum dan sesudah penyuluhan walaupun secara individual ada juga responden yang nilai sesudah penyuluhan menurun dibadingkan dengan nilai sebelum mendapatkan penyuluhan, oleh karena itu dapat disimpulkan bahwa secara umum 
penyuluhan kesehatan dapat meningkatkan pengetahuan responden tentang HIV/AIDS.

Hal ini dimungkinkan bahwa responden lebih senang mendengarkan penjelasan dari fasilitator daripada menggali sendiri pengetahuan melalui diskusi atau dengan kata lain bahwa responden lebih senang menerima pengetahuan (disuapi) dari pada mencari sendiri pengetahuan melalui membaca atau diskusi karena responden masih tergolong muda dan sedikit keingin tahuannnya tentang materi yang dibahas. Hal ini sesuai dengan pendapat Nursalam (2003), semakin cukup umur, tingkat kematangan dan kekuatan seseorang akan lebih matang dalam berfikir dan bekerja, makin tua umur seseorang, makin konstruktif dalam menghadapi masalah yang di hadapi.

Soal/pertanyaan untuk mengungkap pengetahuan responden tentang HIV/AIDS meliputi pengertian, penyebab, gejala/tanda, faktor resiko, pencegahan dan aktifitas yang tidak menularkan HIV/AIDS. Hampir seluruh responden menjawab tepat pertanyaan mengenai pengertian, penyebab, dan pencegahan HIV/AIDS, tetapi masih banyak yang menjawab salah tentang cara penularan dan masih ada stigma pada responden bahwa HIV/AIDS merupakan penyakit keturunan atau kutukan sehingga mereka harus diasingkan.

Rata-rata nilai pengetahuan dengan metode ceramah adalah 83,24 dengan standar deviasi 8,543, sedangkan rata-rata nilai pengetahuan dengan metode diskusi 68,19 dengan standar deviasi 15,309. Hasil uji statistik diperoleh nilai $\mathrm{p}=0.000$ berarti pada alpha 5\% ada perbedaan yang signifikan nilai rata-rata pengetahuan antara metode ceramah dan metode diskusi.

Memperhatikan hasil uji statistik terhadap nilai pengetahuan sebelum dan sesudah penyuluhan kesehatan dengan metode ceramah diperoleh nilai $\mathrm{p}=0.000$, maka dapat disimpulkan ada perbedaan yang signifikan antara nilai pengetahuan sebelum dan sesudah dilakukan penyuluhan kesehatan dengan menggunakan metode ceramah, pada metode diskusi diperoleh nilai $\mathrm{p}=0.003$, maka dapat disimpulkan ada perbedaan yang signifikan antara nilai pengetahuan sebelum dan sesudah dilakukan penyuluhan kesehatan dengan menggunakan metode diskusi, dan hasil uji statistik nilai pengetahuan pada metode ceramah dan diskusi diperoleh nilai $\mathrm{p}=$ 0.000 berarti pada alpha $5 \%$ ada perbedaan yang signifikan nilai rata-rata pengetahuan antara metode ceramah dan metode diskusi

Hipotesis yang diajukan peneliti yaitu, "metode diskusi lebih baik daripada metode ceramah dalam meningkatkan pengetahuan responden tentang HIV/AIDS", namun hasil uji statistik menunjukkan terdapat perbedaan yang signifikan antara metode ceramah dan diskusi yang menunjukkan bahwa metode 
ceramah lebih baik daripada metode diskusi $(\mathrm{p}=$ 0,000). Ini disebabkan karena responden masih terbiasa dengan mendengarkan penjelasan materi melalui ceramah daripada mendapatkan penjelasan melalui diskusi. Hasil tersebut sesuai juga dengan persyaratan menggunakan matode diskusi adalah apabila peserta sudah pernah mendapatkan materi yang di akan dibahas tetapi belum terlalu mendalam memahaminya dan materi yang tepat untuk didiskusikan adalah materi yang menarik atau sedang menarik perhatian peserta, sehingga akan mengakibatkan motivasi peserta lebih baik pada diskusi. Selain itu materi HIV/AIDS kemungkinan tidak menarik untuk dibahas lebih dalam melalui diskusi sehingga peserta tidak serius melaksanakan diskusi, disamping itu waktu yang tersedia untuk diskusipun tidak memadai karena hanya 60 menit.

\section{Simpulan}

1. Pengetahuan responden tentang HIV/AIDS meningkat antara sebelum dan sesudah penyuluhan kesehatan baik dengan metode ceramah maupun dengan metode diskusi.

2. Nilai rata-rata pengetahuan dengan metode ceramah lebih tinggi dibadingkan dengan nilai rata-rata pengetahuan dengan metode diskusi.

3. Ada perbedaan yang signifikan antara nilai pengetahuan sebelum dan sesudah dilakukan penyuluhan kesehatan dengan menggunakan metode ceramah $(\mathrm{p}=0,000), \quad$ ada perbedaan yang signifikan antara nilai pengetahuan sebelum dan sesudah dilakukan penyuluhan kesehatan dengan menggunakan metode diskusi $(\mathrm{p}=0,003)$, dan ada perbedaan yang signifikan nilai rata-rata pengetahuan antara metode ceramah dan metode diskusi $(\mathrm{p}=0,000)$.

\section{Daftar Pustaka}

Depkes RI. 2004 dan 2013. http // Depkes. go. Id

Mansjoer, Arief. 2002. Kapita Selekta Kedokteran. Jakarta, Indonesia

Maryunani, A.dkk, 2009. Pencegahan Penularan HIV dari Ibuke Bayi.Jakarta : Trans Info Media

Mulyawan Arief. Kasus Penderita HIV/AIDS .http://sinarbanten.do.am

Notoatmodjo, Soekidjo. 2010. Metodologi Penelitian Kesehatan. Jakarta : RinekaCipta

Notoatmodjo, Soekidjo. 2010. Pendidikan dan Perilaku Kesehatan. Jakarta : RinekaCipta

Pramudji Ati. Penderita HIV/AIDS. http://sosbud.kompasiana.com (diakses 30 oktober 2011)

Profil Kesehatan Indonesia, 2011

Soenar Yully Dewanti. Kasus HIV/ AIDS.http://www.tempointeraktif.com (diakses 26 juli 2011) 
Sudjana, Nana, 2000, Dasar-dasar Proses

Belajar Mengajar, Sinar Baru Algensindo Bandung

Sudirman, dkk, 1987, Ilmu Pendidikan, Penerbit Remadja Karya Bandung 